\title{
An Investigation of Pun Translatability in English Translations of Sa'di's Ghazals Based on Delabastita's Proposed Model
}

\author{
Fahime Koochacki \\ PNU and IAU of Firuzabad Fars Branch, PO box 7471643353, Firuzabad Fars, Iran \\ E-mail: raha.thelastfly@yahoo.com
}

\author{
Doi:10.7575/aiac.alls.v.7n.4p.147 \\ URL: http://dx.doi.org/10.7575/aiac.alls.v.7n.4p.147
}

Received: 05/04/2016

Accepted: 12/06/2016

\begin{abstract}
The rich cultural connotations behind puns and the distinctive features of the puns' form, sound and meanings pose great challenges to the translator. Furthermore, given puns' non-negligible effects in Persian literary texts, it has been the aim of the present study to analyze and measure how puns in Sa'di's Ghazals have actually been treated in two available English versions. For the purpose of carrying out a meaningful analysis of translated puns, Delabastita's (1996) proposed model was considered as the main theoretical framework of the study. The data were compiled from a corpus comprising 92 ghazals along with their two target versions. Following an exact contrastive analysis of data based on Delabastita's classification and considering the results from the two selected statistical systems of traditional and SPSS in the study, it concluded that the two Iranian translators have applied eight different strategies included in Delabastita's (1996) model. These strategies arranged in descending order based on their total frequencies were Pun $>$ RRD (Related Rhetorical Device); Pun $>$ Non-Punning expressions (both senses); Non-Punning expressions $>$ Pun; Pun $>$ Non-Punning expressions (one sense); Zero $>$ Pun; ST Pun=TT Pun; Pun $>$ Zero and Pun $>$ Pun. Finally, the applicability and feasibility of Delabastita's (1996) model to English translation of puns created in Sa'di's Ghazals were proved.
\end{abstract}

Keywords: language-play, pun, ambiguity, homonymy, homophony, homography, paronymy, translation strategy

1. Introduction

1.1 Overview

Puns are a problem for translators! Two words or phrases that mean different things but sound the same in one language generally do not sound the same in another language. What makes wordplay particularly challenging for a translator is the fact that it employs particular structural characteristics of the source language for its meaning and effect. For these structural characteristics, it is often impossible to find a counterpart in the target language. In words of one syllable, it is obvious that in different countries people have different domains of experience and knowledge. In one domain a word may mean something completely different than what it does in another domain along with rhyme, onomatopoeia, meter and so on, pun can be considered as one of the marked features of poetry that due to its unusual nature and form, and especially its frequently strong dependence on the idiosyncrasies of a particular language can generally be assumed to constitute a significant challenge in a translation context. Furthermore, by virtue of its non-negligible aesthetic effects, the translator is not free to simply ignore the pun without having taken an active stance on its treatment. Nevertheless, the difficulties in finding a proportional TL solution are presumably intensified if the ST is in literary genre, complex or full of rhetorical figures particularly puns, since apart from conveying the content, transferring its formal and aesthetic facets in TT, especially in poetry, is very important.

On the other hand, the arbitrary nature of linguistic symbols which enables a pun sets a very serious obstacle for the translator in translating it into another language, especially when that language is not one that is related to the source language. Then, the translator will have to choose different and dissimilar words instead of similar ones (Weissbrod, 1996, p. 219). Almost all translations of puns give the translator a hard time also regarding the transfer of cultural connotations and specific context-bound shades of meaning, in addition to the question of unavoidable differences between semantic items and their range of meanings and connotations in different languages (Von Flotow, 1997, p. 51). The rich cultural connotations behind puns and the distinctive features of the puns' form, sound and meanings pose great challenges to the translator. Pusch (von Flotow, 1997, p. 52). argues that wordplay seldom translates adequately, and a surplus of 'untranslatable' wordplay, accompanied by copious translator's notes, defeat the aim of readability; which is an important factor in Sa'di's works, particularly in his ghazals. He accepts that wordplay adds taste to the text or discourse, and one takes pleasure in reading it because it triggers unexpected connections between concepts, sounds and words in the reader, creating a sense of specialized perception and 'knowledge', even a sense of connivance with the author. Nevertheless, he thinks the translation of wordplay is risky and in places tedious because different languages organize their concepts, sounds and words differently.

1.2 Statement of the problem

What makes wordplay particularly challenging for a translator is the fact that it employs particular structural characteristics of the source language for its meaning and effect. For these structural characteristics, it is often impossible 
to find a counterpart in the target language. On the other hand, the rich cultural connotations behind puns and the distinctive features of the puns' form, sound and meanings pose great challenges to the translator.

By virtue of its non-negligible aesthetic effects, the translator is not free to simply ignore the pun without having taken an active stance on its treatment. Nevertheless, the difficulties in finding a proportional TL solution are presumably intensified if the ST is in literary genre, complex or full of rhetorical figures particularly puns, since apart from conveying the content, transferring its formal and aesthetic facets in TT, especially in poetry, is very important.

\subsection{Significance of the Study}

More often than not poetry, at least its classical variety, contains language-play. The kind relying on sounds, like rhyme, alliteration and puns, predominates. In Smith's (2000, p. 56) word, poetry is a type of language use in which different features are intermingled to function in a certain way. One of these features is sound which has as an aesthetic value tied to the cognitive meaning, and not only is it applied for its sheer beauty and charm but also fused with action to convey the vivid sense of event and meaning and the translator has to be ever mindful of the author's purposeful interlinking between the aesthetic value of sound and the cognitive meaning of the text.

Along with rhyme, alliteration, meter, onomatopoeia and so on, pun, as one of the marked features of poetry, has arisen challenge and debate in the course of the translation process since in creating pun form contributes into sense; pun as significant component of poetry which has semantic as well as aesthetic value is frequently found in the canonized texts such as Sa'di's poems.

Yet, pun study has not drawn the attention it deserves by either professionals or language experts. As translation studies are quite new compared to other disciplines anyway, it is needless to say that studies on the translation of puns are quite scarce. It is no doubt that a study on the translation of English and Persian puns is of great significance and affords much pleasure. As translation studies are quite new compared to other disciplines anyway, it is needless to say that studies on the translation of puns are quite scarce. Therefore, the present study is thought to be the first example on the issue of pun translatability in Sa'di's Ghazals and to be the broadest study.

Sa'di is very fond of puns and as one of the famous punsters in classic Persian literature plays with language throughout his works, which have many witty word plays uses puns to good effect in his works. So logically, the widespread occurrence of pun in all text types particularly in poems and its major part in Sa'di's Ghazals demands a study evaluating the applicability of such strategies suggested for translating pun in the Persian context. So among purposed approaches for translating puns, Delabastita's (1996) set of techniques seems to fulfill the criteria such as applicability, justifiability and the generality for the translation of language-play, narrowing its domain down to translating of puns.

\subsection{Objectives of the Study}

In a nutshell, the present study was an attempt to fulfill the main objectives as follows:

1) Drawing attention to the typology of pun as well as some remarkable strategies proposed to render it; 2) Investigating the way pun has been dealt with by the two Iranian translators of Sa'di's Ghazals; 3) Identifying the most and the least frequently used strategies in terms of two available statistical systems; and 4) Evaluating the feasibility and applicability of Delabastita's (1996) set of techniques to English translation of Persian puns as a theoretical framework of the study.

\subsection{Research Questions}

Considering the aforementioned objectives, this piece of research attempts to examine how the two Iranian translators of Sa'di's Ghazals - Simindokht Seyedfatah (1999) and Saeed Saeedpoor (2009) -deal with a selection of puns in Sa'di's poetries; moreover, it aims to seek answers to the following questions:

1) Are puns translatable?

2) What strategies have been applied to render puns into English translation(s) of Sa'di's Ghazals based upon Delabastita's (1996) classification?

3) Which strategies are the most and the least frequently used for English translation of the puns created in Sa'di's Ghazals?

4) Is Delabastita's (1996) proposed model applicable to translate puns in Sa'di's Ghazals?

\section{Literature Review}

\subsection{Definitions of Pun}

Punning is an ingenious use of homophonic and polysemous phenomena of language with an intention to achieve special effects. As a rhetorical device with strong expressive power it is widely employed in all forms of linguistic communication, ranging from daily conversation to literary works, from advertisements to news reports, and from riddles to jokes.

According to The Oxford English Dictionary (OED), pun is defined as 'the use of word in such a way as to suggest two or more meanings or different associations, or the use of two or more words of the same or nearly the same sound with different meanings, so as to produce a humorous effect'. In Princeton Encyclopedia of Poetry and Poetics (PEPP), pun is defined as 'A figure of speech depending upon a similarity of sound and a disparity of meaning'. In Crisafulli's (1996, p. 261) words, Pun can be defined as creating meaningful associations between words that are similar in form but different in meaning.

Dirk Delabastita(1996, p. 31), a scholar of Translation Studies doing numerous studies and research on punning and its translation, declares that the pun is most common in languages like English which have many monosyllabic words and suggests a more cognitive and linguistic definition as follows: "Pun is a general name for the various textual phenomena in which structural features of the language used are exploited in order to bring about a communicatively significant 
confrontation of two linguistic structures with more or less similar forms and with more or less different meanings" (1996, p. 31).

2.2 Subtypes of Pun

From the duality of meaning and form, it is constructed the structure of puns, which is two-fold. Firstly, puns are divided into different types of puns (Gottlieb, 1997, p. 210), based on their formal identity (Delabastita, 1996, p. 128), and secondly, they are divided into vertical and horizontal puns, depending on the presence of their component parts. The following section is intended to provide an abstract of the different types of pun.

\subsubsection{Bilingual Pun}

There is a special type of pun, namely the bilingual pun, which involves different languages whose semantic territories (Delabastita, 1993) overlap. According to Delabastita, (1993, p. 154) [t]he possibility of such bilingual wordplay rests on the fact that phonemic systems of different languages may share individual properties (regarding phonemic structure, rules for phoneme distribution, etc.), allowing the punster to take advantage of supralingual formal (phonetic) similarity. This similarity can be, but need not be complete: the fact that it is not may actually be a source of extra fun. But for the pun to be possible it has to be strong enough to bring about the coupling of disparate meanings. It should be mentioned that this type of pun go beyond the scope of this study.

2.2.2 Vertical Pun

Delabastita (1996, p. 623) defines vertical pun as a type of pun which relies on a simultaneous double context enabling a double meaning. In other words, puns where the competing meanings are evoked by a single occurrence of the ambiguous item or items are now generally referred to as vertical puns. The punning words may clash associatively by being co-present in the same portion of text. The vertical pun is regarded to be the same as ambiguity, hence in Delabastita's (1996, p. 623) distinction ambiguity is a subcategory of pun. Interestingly, the same relationship exists between pun and ambiguity in Persian. As a case in point, take the following Persian couplet into consideration:

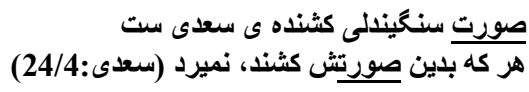

\section{/Soorat e sangindeli koshandeh ye Sa'di st/ /Har ke bedin sooratash koshand, namirad ( Sa'di:24/4)/}

In the above example, the word /soorat/ conveys two meanings; considering the words 'soorat' in the first hemistich, the term /soorat/ signifies the meaning of 'face and visage'; moreover, with respect to the word 'bedin' in the second line, its other possible meaning is 'manner or aspect'.

Dr. Sokhango (1979, p. 19) discussing the relationship between pun and ambiguity in Persian poetry declares that the relationship between these two is not an external one related to the surface structure, but an internal one related to the deep structure. In a way that, ambiguity can be supposed as a surface structure established on pun, a pun whose two or more surface meanings are transformed into a single surface structure, but in which the polysemy still exists.

Before dealing with the other types of pun in the next section, it had better to add a few remarks on ambiguity, which is a term commonly employed when describing the nature of a pun, at least the vertical varieties. By far the most prominent viewpoint in the field of ambiguity belongs to Newmark (1988, p. 128), which it is sufficed to mention their titles here only: Lexical Ambiguity; Grammatical Ambiguity; Referential Ambiguity; Metaphorical Ambiguity; Idiolectal Ambiguity; Pragmatic Ambiguity and Cultural Ambiguity.

2.2.3 Horizontal Pun

Horizontal pun, according to Delabastita (1996, p. 623), relies on the consecutiveness of linguistic components to set forth the double meaning. In other words, puns where the different meanings are each connected to their own signifier. In this type of pun, the punning words are in a relation of continuity by occurring one after another in a text. In horizontal puns, according to Delabastita (1996, p. 128) and Gottlieb (1997, p. 210), the formal identity, whether complete or partial, is expressed through homonymy: lexical elements with the same sound and spelling, for instance, the homonymous words /ravaan/ in the following Persian couplet represent two different meanings of 'walking' as well as 'soul and life' despite the formal identity in sound and spelling:

\section{/Mahmel bedaar ey saarebaan tondi makon ba kaaravaan/ /Kaz eshq e aan sarve ravaan gooee ravaanam miravad( Sa'di: 63/3)/}

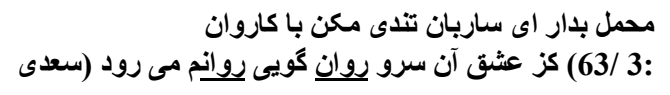

Homophony: lexical elements with the same sound but different spelling, it is need to say that the homophony is the most infrequently category of pun, at least in this study it found only in one case as follows:

/Begrist chashm e doshman e man bar hadis e man/

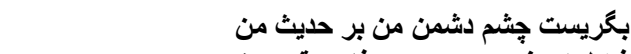
/Fazl az gharib hast va vafaa dar qarib nist( Sa'di: 127/7)/ 
In the above-mentioned couplet, the two words of / gharib/ and /qarib/ play a role of the homophonic words.

Homography: lexical elements with the same spelling but different sound, as stated in the following example, the two words of $/ \mathrm{mohr} /$ and $/ \mathrm{mehr} /$ as well as the words $/ \mathrm{sar} /$ and $/ \mathrm{ser} /$ enjoy a homographic relationship:

/Ey mehr e to dar delhaa, vey mohr e to bar labhaa/

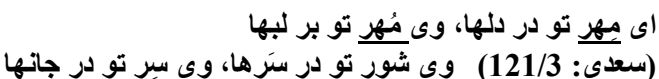

/Vey shoor e to dar sar ha, vey ser e to dar janhaa( Sa'di: 121/3)/

and paronymy: lexical items with partially same spelling and sound, as an example, the following couplet contains the two words of /salaamat/ and /malaamat/ which are considered as subcategories of the paronymic pun:

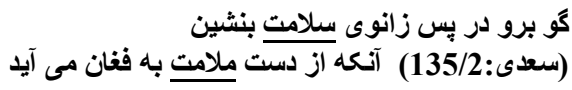

/Goo boro dar pas e zaanoo ye salaamat benshin/

/Aanke az dast malaamat be faghaan miaayad( Sa'di: 135/2)/

\subsection{Translation Strategies of Puns}

Many translation strategies have been formulated for the translation of different kinds of wordplay in different text types, and even in different media, which here can be specialized in strategies for translating pun. For example, de Vries \& Verheij (1997, p. 72) have proposed the following strategies for translating the wordplay occurred in Bible:

a) Pun by Pun;

b) Pun to rhetorical device -including alliteration, assonance and rhyme;

c) Transliteration -literal translation of words;

d) Compensation -in adjacent text fragment.

Likewise, Gottlieb (1997, p. 210) has discussed audiovisual wordplay translation in his essay on subtitling and finally he has presented the translation strategies for treating it as follows:

a) Adaptation - to local setting, maintaining humorous effect;

b) Replaced by Non-Wordplay;

c) Not rendered;

d) Rendered verbatim;

e) Compensation- in different position.

Amongst those proposing distinct translation strategies for pun, there are some literary tactics which are suggested by Weissbrod (1996, p. 46, 221) such as:

a) Employing all stylistic levels and historical strata accessible in the target language, even if they have no parallel in the source text;

b) changing one or more of meaning(s) of the original pun so that they can be condensed again into one word or words similar in form or sound;

c) Changing which includes the use of any type of pun in the target text for a source text pun.

The last two inventories of strategies that the researcher would like to mention have been developed in the context of Shakespeare's puns in translation. The first is Offord's.

Offord (1990, p. 119, quoted in Offord, 1997, p. 241) suggests more distinct strategies including:

a) Imitating the source text pun;

b) Mentioning both meanings of the source text pun;

c) Rendering the source text pun into a non-punning expression in the target text which includes the surface source meaning;

d) Rendering the source text pun into a non-punning expression in the target text including the underlying source meaning;

e) Create new wordplay;

f) Ignoring pun.

Obviously, the reference to Shakespeare could easily be edited out from this list and the result would be valid for wordplay in general.

Delabastita (1993, p. 191-221), finally, proposes and discusses a more comprehensive list composed of nine "translation techniques" for dealing with pun, which, as he himself points out, may also be used in combination. They are quite straightforward and seem to cover all conceivable scenarios. This list is as follows:

a) PUN > PUN: more or less different from the original wordplay in terms of formal structure, semantic structure, or lexical function;

b) PUN > NON-PUN (both senses): the pun is rendered by a non-punning phrase which may salvage both senses of wordplay but in a non-punning conjunction; 
c) PUN > NON-PUN (one sense): the pun is rendered by a non-punning phrase which may select one of the senses at the cost of suppressing the other; of course, it may also occur that both components of the pun are translated 'beyond recognition';

d) PUN > RELATED RHETORICAL DEVICE (RRD or Punoid): the pun is replaced by some wordplay related rhetorical device (repetition, alliteration, rhyme, referential vagueness, irony, paradox, etc.), which also aims to recapture the effect of the source-text pun;

e) PUN ST = PUN TT: the translator reproduces the source-text pun and possibly its immediate environment in its original formulation, i.e. without actually 'translating' it;

f) PUN > ZERO: the portion of text containing the pun is simply omitted;

g) NON-PUN > PUN: the translator introduces a pun in textual positions where the original text has no wordplay, by way of compensation to make up for source-text puns lost elsewhere, or for any other reason;

h) ZERO > PUN: totally new textual material is added, which contains wordplay and which has no apparent precedent or justification in the source text except as a compensatory device;

i) EDITORIAL TECHNIQUES: explanatory footnotes or endnotes, comments provided in translator's forewords, the anthological presentation of different, supposedly complementary solutions to one and the same source-text problem, and so forth" (1996, p. 134).

\section{Methodology}

\subsection{Materials}

The data were collected by analyzing two English translations of Sa'di's Ghazals, which are as follows:

1. The English version of Sa'di's Ghazals translated by Simindokht Seyedfatah (1999).

2. The English version of Sa'di's Ghazals translated by Saeed Saeedpoor (2009).

There were two main reasons for such a selection. The first reason was that although many works of sa'di, whether in prose or poetry, have been already translated to different languages, his Ghazals- apart from a few ghazals sporadically have been translated to a heavy and literary language after studying his works and personality- hasn't been rendered long. Its reason is unknown. Only these two translators made a success of rendering this precious work. The second reason was that the version translated by Seyedfatah (1999) seems to be comprehensive despite the fact that it includes not more than seventy and two ghazals. In addition, The English version translated by Saeedpoor (2009) was chosen as the second version owing to the fact that it is the most recent translation of Sa'di's Ghazals. There won't be any tendency to compare the English translations in terms of such translation norms as accuracy or economy, but it will be directed to describe how pun has been dealt with in order to judge about the translatability of pun, and such a result can be obtained through the existing translations.

3.2 Data Collection and Analysis Procedures

The procedure for getting the required data was composed of eight components gathered together in two stages. The first four items are attributed to stage I of the data analysis, including

(1) Reading the whole Sa'di's Ghazals in Persian;

(2) Detecting couplets containing puns;

(3) Finding their equivalents in the English versions and

(4) Identifying the translation strategies applied based on Delabastita's proposed model.

The second four components form stage II of the data analysis; that is,

(1) Reading the whole Sa'di's Ghazals in English;

(2) Detecting couplets containing English puns created in TT;

(3) Finding their counterparts in the Persian version and

(4) Identifying the translation strategies applied based on Delabastita's taxonomies.

Detecting couplets containing puns (whether in stage I or II) on its own consists of the two parts: At the first part, the couplets containing a pun or more were recognized and at the second one, the detected puns were categorized in terms of pun typology (using Delabastita`s classification) into vertical puns and horizontal puns composed of homonymy, homophony, homography and paronymy.

3.3 Unit of Translation

In this study, the researchers have been employed one couplet consisting pun as the logical unit of translation. It should be emphasized that pun was the focus of attention in each unit of translation. In other words, the researchers have chosen puns existing in each UT as the data for her study.

\section{Data Analysis and Results}

\subsection{Data Analysis}

In the context of investigation that forms the core of this study, it must be pointed out that the main feature of this research is the recognition and discussion of representative instances of the various categories of pun included in Sa'di's Ghazals, on the one hand, and analyzing and comparing them with their English counterparts and entirely identifying the adopted translation strategies by the two Iranian translators based upon Delabastita's framework (1996), on the other hand. It is also intended to yield statistical and meaningful results in terms of frequencies and chi-square tests. In order to support such an approach, a collection of 92 Sa'di's selected Ghazals along with its respective translations has been 
compiled. The first section has been dedicated to the various categories of pun and their analyses and function in two stages. Stage I primarily tackles to recognize, analyze and elaborate on the five subcategories of pun (i.e. vertical pun; homonymy, homography, homophony and paronymy, as the subsets of horizontal pun) created in the source text. Then it compares these categories with their TL equivalents and identifies the adopted translation strategies based on Delabastita's taxonomies (1996). However, stage II of this section performs vice versa. In other words, the systematic processes of recognition and analysis of puns start from the production; i.e. translated text, and terminate to compare with the original counterparts and identify the adopted translation strategies. In all, 338 instances of five subcategories of pun, including 176 instances of ST puns and 165 instances of TT puns, have been identified. The identified puns were classified into nine categories based upon Delabastita's (1996) proposed model. It shouldn't be forgotten that the pun varieties in the Persian language were more than English one. Nevertheless, the last recognition and analysis Persian puns were also based on Delabastita's proposed model for rendering five given pun categories. In the following, Tables $1 \& 2$ represent some random instances of 176 ST and 165 TT puns identified in Stages I and II of the study, respectively, which have been analyzed based on Delabastita's (1996) model to translate pun categories.

Table 1. Some Random Examples of ST Puns Identified in Stage I of the Study in Parallel the Translation Strategies Adopted by the Two Iranian Translators

\begin{tabular}{|c|c|c|c|c|}
\hline Pun Typology & Persian Puns & Underlying & $\begin{array}{l}\text { English } \\
\text { Equivalents }\end{array}$ & $\begin{array}{l}\text { Translation } \\
\text { Strategies }\end{array}$ \\
\hline Vertical & & $\begin{array}{l}\text { Love/Lovely fancy and } \\
\text { imagination / Frenzy }\end{array}$ & the passion & Pun $>$ Pun \\
\hline Vertical & /حرم/Haram/ & $\begin{array}{l}\text { Port and anchorage/ refuge } \\
\text { and shelter }\end{array}$ & Haven & $\begin{array}{l}\text { Pun }>\text { RRD (in } \\
\text { form of alliteration) }\end{array}$ \\
\hline Vertical & /خليلxalil/ & $\begin{array}{l}\text { Abraham's title / the beloved } \\
\text { or friend }\end{array}$ & Abraham & $\begin{array}{l}\text { Pun }>\text { Non-Pun } \\
\text { (one sense) }\end{array}$ \\
\hline Homonymy & $\begin{array}{l}\text { تتها / تنها /Tanhaa/ } \\
\text { /Tan }\end{array}$ & Bodies / alone or only & $\begin{array}{l}\text { So many bodies / } \\
\text { the only }\end{array}$ & $\begin{array}{l}\text { Pun }>\text { Non-Pun } \\
\text { (both senses) }+ \\
\text { Pun }>\text { RRD (in } \\
\text { form of repetition } \\
\text { of sounds } / \mathrm{o} / \& / \mathrm{y} /\end{array}$ \\
\hline Homonymy & حلقه/ حلقه & Group / hoop & The ring / the ring & Pun $>$ Pun \\
\hline Homography & $\begin{array}{l}\text { سربريدن/سر بريدن } \\
\text { sar boridan /sar e } \\
\text { boridan }\end{array}$ & $\begin{array}{l}\text { Head to be cut off/ with the } \\
\text { intention to separate }\end{array}$ & $\begin{array}{l}\text { Head to be cut off/ } \\
\text { to cut off from }\end{array}$ & Pun $\mathrm{ST}=$ Pun TT \\
\hline Homography & $\begin{array}{l}\text { آخر / آخر } \\
\text { aaxer / aaxar }\end{array}$ & $\begin{array}{l}\text { The end / anyhow or any } \\
\text { more }\end{array}$ & an end / at last & Pun $>$ Zero \\
\hline Homophony & $\begin{array}{l}\text { قريب / غريب / qarib } \\
\text { gharib / }\end{array}$ & A stranger / the beloved & $\begin{array}{l}\text { A stranger/ the } \\
\text { beloved }\end{array}$ & $\begin{array}{l}\text { Pun }>\text { Non-Pun } \\
\text { (both senses) }+ \\
\text { Pun }>\text { RRD (in form } \\
\text { of rhyme by } \\
\text { repeating the word } \\
\text { 'me' at the end of } \\
\text { both hemistiches) }\end{array}$ \\
\hline Paronymy & 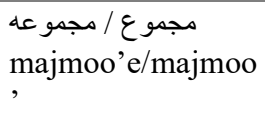 & Collection/ fit or tranquil & a whole/ the whole & $\begin{array}{l}\text { Pun ST = Pun TT } \\
\text { (literally translated) }\end{array}$ \\
\hline Paronymy & $\begin{array}{l}\text { بارس / بارسا } \\
\text { Paarsaa/ Paars }\end{array}$ & Virtuous or devout/ Persian & $\begin{array}{l}\text { Who is virtuous / } \\
\text { Persian }\end{array}$ & $\begin{array}{l}\text { Pun }>\text { Non- Pun } \\
\text { (both senses) } \\
+ \text { Pun }>\text { RRD (in } \\
\text { form of repetition } \\
\text { of sounds } / \mathrm{r} / \& / \mathrm{s} / \\
\text { all over the English } \\
\text { couplet) }\end{array}$ \\
\hline
\end{tabular}


Table 2. Some Random Examples of TT Puns Identified n Stage II of the Study in parallel the Translation Strategies Adopted by the Two Iranian Translators

\begin{tabular}{|c|c|c|c|c|}
\hline $\begin{array}{c}\text { Pun } \\
\text { Typology }\end{array}$ & English Puns & $\begin{array}{l}\text { Underlying } \\
\text { Meanings }\end{array}$ & $\begin{array}{l}\text { Persian } \\
\text { Equivalents }\end{array}$ & $\begin{array}{l}\text { Translation } \\
\text { Strategies }\end{array}$ \\
\hline Homonymy & Tender / tender & $\begin{array}{l}\text { Delicate (adj) / } \\
\text { submit (vt) }\end{array}$ & $\begin{array}{l}\text { نكه دارش/ نازك/negahdaarash } \\
\text { Nazok/negal }\end{array}$ & Non-Pun $>$ Pun \\
\hline Homophony & Whole / hole & $\begin{array}{l}\text { Everybody } \\
\text { /penetration }\end{array}$ & $\begin{array}{l}\text { رخنه / هر كه } \\
\text { Harke/rekhne }\end{array}$ & Non-Pun $>$ Pun \\
\hline Paronymy & Face / faith & Visage/ religion & $\begin{array}{l}\text { زنار / عارض/zonaar } \\
\text { Aarez/2 }\end{array}$ & $\begin{array}{l}\text { Non-Pun }>\text { Pun }+ \\
\text { Pun }>\text { RRD (in } \\
\text { form of rhyme) }\end{array}$ \\
\hline Paronymy & Sick / seek & Love- sick / look for & $\begin{array}{l}\text { - غ / / / / } \text { - } \\
\text { gham e doost }\end{array}$ & $\begin{array}{l}\text { Zero }>\text { Pun }+ \text { Pun }> \\
\text { RRD (in form of } \\
\text { rhyme) }\end{array}$ \\
\hline Paronymy & Sage / cage & $\begin{array}{l}\text { Wise, intelligent/ } \\
\text { cage }\end{array}$ & $\begin{array}{l}\text { - / قفسى } \\
\text {-/ qafasi }\end{array}$ & $\begin{array}{l}\text { Zero }>\text { Pun }+ \text { Pun }> \\
\text { RRD (in form of } \\
\text { rhyme) }\end{array}$ \\
\hline Paronymy & Wit's / with & $\begin{array}{l}\text { in a metaphor } \\
\text { expression: be } \\
\text { wandering / by, with }\end{array}$ & $\begin{array}{l}\text { أبه / hidden in } \\
\text { content } \\
\text { Be jaan aamad/ } \\
\text { hidden in content }\end{array}$ & $\begin{array}{l}\text { Non-Pun }>\text { Pun }+ \\
\text { Pun }>\text { RRD } \\
\text { (in form of } \\
\text { metaphorical } \\
\text { expression: 'is at } \\
\text { his wit's end) }\end{array}$ \\
\hline
\end{tabular}

\subsection{Result}

Regarding the analyzed data based on Delabastita's (1996) proposed model, It was found that from the nine translation strategies presented in Delabastita's model (1996), there are eight strategies of translation applied by the two translators. This list is as follows: 1) PUN $>$ PUN, 2) PUN $>$ NON-PUN (one sense), 3) PUN $>$ NON-PUN (both senses), 4) PUN $>$ Related Rhetorical Device (RRD or Punoid), 5) PUN $>$ ZERO, 6) PUN ST=PUN TT, 7) NON-PUN $>$ PUN, 8) ZERO $>$ PUN. It is noteworthy to mention that most often two strategies interact in a single instance of pun which each one of them is counted by itself. The only strategy of Editorial Techniques has not been applied by the two Iranian translators.

Considering the main focus of the present study, Table 3 displays the frequencies of eight applied translation strategies by the two Iranian translators for rendering five pun categories created in 92 Ghazals of Sa'di. In the first column of this Table, the eight translation strategies are arranged in descending order based on their total frequencies. Five categories of puns have occupied the cells of the first rows. The total frequencies of translation strategies are amounted in the last two columns, in terms of number and percentage.

Table 3. Frequency of Strategies Applied by the Two Iranian Translators, for English Translation of Pun Categories Created in Sa'di's Ghazals

\begin{tabular}{|c|c|c|c|c|c|c|c|}
\hline \multirow[t]{3}{*}{$\begin{array}{l}\text { Translation } \\
\text { Strategies }\end{array}$} & \multicolumn{5}{|c|}{ Categories of Pun } & \multicolumn{2}{|c|}{$\begin{array}{l}\text { Total } \\
\text { Frequency }\end{array}$} \\
\hline & \multirow[b]{2}{*}{$\begin{array}{l}\text { Ver. } \\
\text { Pun }\end{array}$} & \multicolumn{3}{|c|}{ Hor. Pun } & & \multirow[b]{2}{*}{ NO. } & \multirow[b]{2}{*}{$\%$} \\
\hline & & Homonymy & Homography & Homophony & Paronymy & & \\
\hline Pun $>$ RRD & 17 & 48 & 4 & 1 & 107 & 177 & 30.41 \\
\hline $\begin{array}{l}\text { Pun }>\text { Non-Pun } \\
\text { (both senses) }\end{array}$ & 12 & 49 & 8 & 1 & 95 & 165 & 28.35 \\
\hline Non-Pun $>$ Pun & $\varnothing$ & 7 & $\varnothing$ & 7 & 89 & 103 & 17.69 \\
\hline $\begin{array}{r}\text { Pun }>\text { Non-Pun } \\
\text { (one sense) }\end{array}$ & 39 & 2 & $\varnothing$ & $\varnothing$ & $\varnothing$ & 41 & 7.04 \\
\hline Zero $>$ Pun & $\varnothing$ & $\varnothing$ & $\varnothing$ & $\varnothing$ & 28 & 28 & 4.81 \\
\hline PunST=PunTT & 4 & 14 & 1 & $\varnothing$ & 5 & 24 & 4.12 \\
\hline Pun $>$ Zero & 2 & 2 & 1 & $\varnothing$ & 18 & 23 & 3.95 \\
\hline Pun $>$ Pun & 9 & 8 & $\varnothing$ & $\varnothing$ & 4 & 21 & 3.60 \\
\hline
\end{tabular}

Ver. Pun $=$ Vertical Pun Hor. Pun $=$ Horizontal Pun $\quad$ RRD $=$ Related Rhetorical Device 
However, a comparison of the research findings presented in Table 3 indicates that there are major differences between the observed frequencies of the identified strategies. In order to determine whether these differences are significant, the chi-square $(\chi 2)$ test was applied. To begin with, the chi-square values were computed in the traditional statistical system. The total $\chi 2$ values computed in traditional system for the eight strategies employed by the two Iranian translators are displayed in Table 4.

Table 4. The total $\chi 2$ Values Computed in the Traditional Statistical System for the Eight Strategies Employed by the Two Iranian Translators

\begin{tabular}{ccccc}
\hline Translation Strategy & Observed F. & Expected F. & Residual & $\chi 2$ Value \\
\hline PUN>RRD & 177 & 72.8 & 104.2 & 149.14 \\
\hline $\begin{array}{c}\text { Pun>Non-Pun } \\
\text { (both senses) }\end{array}$ & 165 & 72.8 & 92.2 & 16.76 \\
\hline $\begin{array}{c}\text { Non-Pun>Pun } \\
\text { Pun>Non-Pun } \\
\text { (one sense) }\end{array}$ & 103 & 41 & 72.8 & 30.2 \\
\hline Zero>Pun & 72.8 & -31.8 & 13.89 \\
\hline Pun ST=Pun TT & 24 & 72.8 & -44.8 & 27.56 \\
\hline Pun >Zero & 23 & 72.8 & -48.8 & 32.71 \\
\hline Pun>Pun & 21 & 72.8 & -49.8 & 34.06 \\
\hline
\end{tabular}

Critical Value $=14 / 07$

Expected value $=72 / 75 \approx 72 / 8$

Looking at Table 4., it is clear that the chi-square values for most of the strategies employed by the two Iranian translators, are greater than the critical value of 14.07 which, in degree of freedom 7 ( total number of applied strategies- 1), is required for significance at the 0.05 level of test. This finding indicates that the differences observed between the frequencies of the strategies, are statistically significant and could not simply have happened by chance.

Finally, in order to provide more exact statistical results on a widespread scale of this study, the chi-square test was conducted in modern statistical system; i.e. SPSS software. The output of the test included in Tables 5 and 6 represents the existence of significant differences in the eight translation strategies adopted by the two Iranian translators. On the basis of these Tables, the extent of p-value is very smaller than the level of the test. In other words, $p$-value equals 0.000 which implies that there is a certain significant difference between the eight translation strategies applied by the two Iranian translators.

Table 5. The P-Values Computed in the Statistical System of SPSS for the Eight Strategies Employed by the Two Iranian Translators

\begin{tabular}{|c|c|c|c|}
\hline \multicolumn{4}{|c|}{ Test Statistics } \\
\hline & & & VAR00006 \\
\hline & & Chi Square & 423.828 \\
\hline & & Df. & 7 \\
\hline & & Asymp. Sig. & $.000^{\mathrm{a}}$ \\
\hline \multirow{3}{*}{ Monte Carlo Sig. } & \multirow{3}{*}{$\begin{array}{l}99 \% \\
\text { Confidence Interval }\end{array}$} & Sig. & $.000^{\mathrm{b}}$ \\
\hline & & Lower Bound & .000 \\
\hline & & Upper Bound & .000 \\
\hline
\end{tabular}

a. 0 cells $(.0 \%)$ have expected frequencies less than 5 . The minimum expected cell frequency is 72.8 .

b. Based on 10000 sampled tables with starting seed 303130861.

Asymp. Sig = approximate $p$-value

Monte Carlo Sig = exact $p$-value 
Table 6. The P-Values computed in the Statistical System of SPSS for the Eight Strategies Employed for English Translations of the Puns Created in Sa'di's Selected Ghazals by the Two Iranian Translators Based on Pearson ChiSquare

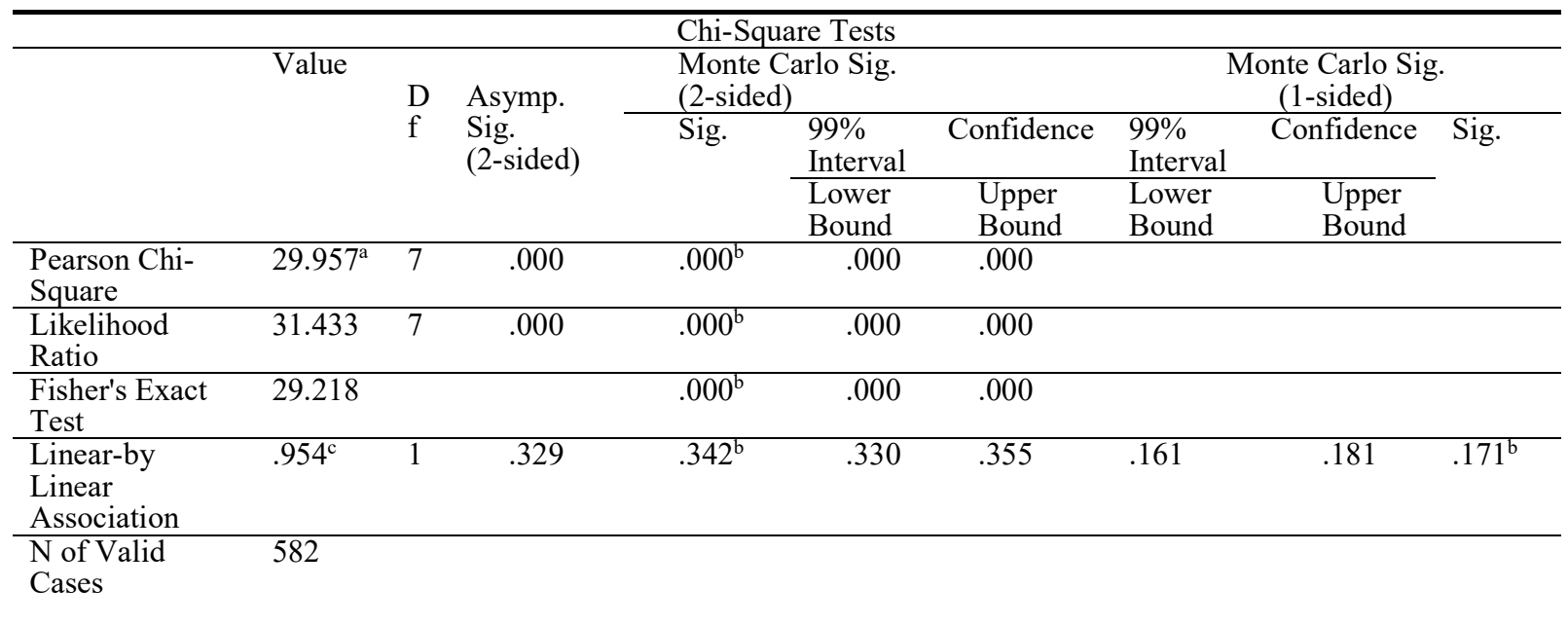

a. Cells (6.3\%) have expected count less than 5. The minimum expected count is 4.94 .

b. Based on 10000 sampled tables with starting seed 1993510611.

c. The standardized statistic is -.977 .

\section{Conclusion and Discussion}

5.1 Conclusion

With regard to the findings of the study included in Table 3, the most frequently applied strategy in all the translations of Sa'di's Ghazals is the strategy of Pun > RRD (Pun to Related Rhetorical Device), with a total frequency of $30.41 \%$. The great portion of the paronymic puns (107 instances) has been rendered via this strategy. Moreover, it has played a considerable role in translation of homonymic puns so that over half of the homonymic puns detected in the ST; i.e. 48 out of 74 homonymic puns, have been translated by it.

The second status considering the extent of using Delabastita's proposed strategies has been dedicated to the strategy of Pun $>$ Non-Pun (both senses), with a frequency difference 12 in proportion to the strategy of Pun $>$ RRD. Its total frequency equals $28.35 \%$. Moreover, it is the most commonly used strategy for the translation of paronymic puns detected in the source text. Indeed, 95 out of 123 paronymies found in the original text, have been rendered via the strategy of Pun $>$ Non-Pun (both senses). The other puns including homonymy (49 instances), vertical pun (12 instances), homography (8 instances) and at last homophony (1 instance) are in the subsequent ranks for the usage of this strategy. Considering the corresponding chi-square values resulted from the strategies of Pun>RRD (149.14) and Pun $>$ Non-Pun (both senses) (116.76), as displayed in Table 3, there is a significant difference between the two strategies and the rest of them. In other words, the two strategies are remarkably greater than the given critical value (14.07) in the traditional statistical system.

The third and fourth ranks with respect to the extent of their applicability in the translations of Sa'di's Ghazals belong to the translation strategies of Non-Pun $>$ Pun and Pun $>$ Non-Pun (one sense), respectively. Regarding their corresponding chi-square values; i.e. 12.52 for Non-Pun $>$ Pun and 13.89 for Pun $>$ Non-Pun (one sense), which are less than the required critical value for being significant in an accepted level considering $\mathrm{df}=7$, the null hypothesis for the special strategies is accepted. In fact, the two strategies do not differ significantly from the others.

The remaining four strategies in the bottom of Table 3; i.e. the strategies of Zero $>$ Pun, Pun ST $=$ Pun TT, Pun $>$ zero and Pun $>$ Pun, having a negligible difference in their frequencies $(28,24,23,21$, respectively), have occupied the ranks from fifth to eighth for applicability in the translations of the original text. With regard to the corresponding chi-square values of the four strategies $(27.56,32.71,34.06,36.85$, respectively), it can be concluded that these strategies are among the translation strategies which contain the significant difference from the others. Indeed, the four strategies along with the strategies of Pun $>$ RRD and Pun $>$ Non-Pun (both senses) make a significant difference in all the translation strategies applied in the study and in a word, the null hypothesis will be rejected in them.

At last, after conducting a set of statistical processes in SPSS software, the output was arranged in a descriptive table. With respect to Table 5, the quantity of p-value for the total chi-square value of 423.828 in terms of degree of freedom 7 in both forms of significances; i.e. Asymp. Sig. and Monte Carlo Sig., equals 0.000 . Therefore, since the extent of pvalue is less than 0.05 ( $p$-value $\leq \alpha$ ), the null hypothesis is not accepted. With the result that the extent of applying all eight adopted strategies is not identical and there is a significant difference between Observed Frequency and Expected Frequency from eight strategies employed in the translation(s) of Sa'di's Ghazals.

5.2 Discussion

The first dilemma that the present study was aimed to resolve is whether pun was translatable or not. The pre-eminent proponents of pun translatability such as Toury (1997), Gottlieb (1997), Landheer (1989) and Delabastita (1996) argue that languages are not as different from each other as some proponents of the untranslatability theory seem to think; all languages share some features with other languages and pun as a common and universal feature of all languages is 
translatable. As for, Considering the eight various strategies applied to rendering puns in Sa'di's Ghazals, which more or less have been organized to transfer the ST effect, it can be deduced that translatability is a relative notion rather than an absolute one.

The second purpose of the present study was to identify the different strategies applied to English translation of the pun categories created in Sa'di's selected Ghazals by the two Iranian translators. Delabastita's (1996) classification for translating puns was considered for the compilation and analysis of the research data. Among the nine proposed strategies, the similar eight strategies with the different rankings of applicability were employed by the two translators, including Pun $>$ RRD (Related Rhetorical Devices), Pun $>$ Non-Pun (both senses), Non-Pun $>$ Pun, Pun $>$ Non-Pun (one sense), Zero $>$ Pun, Pun ST=Pun TT, Pun $>$ Zero and Pun $>$ Pun (See Table 3). Only one proposed strategy of Editorial Techniques was not applied by any of the aforementioned translators. This matter does not account for the inadequacy of such strategies in translating pun, but it can imply that the nature of Sa'di's Ghazals due to its being easy but difficult to imitate and also easy to understand requires the jettison of this strategy, not the inadequacy of the strategy on its own. Another reasonable objective of this study was to detect the most and the least frequently used of adopted strategies in the English translations of Sa'di's Ghazals. In terms of the output extracted from the chi- square tests in both statistical traditional and SPSS systems, the two most frequently used strategies of Pun $>$ RRD and Pun $>$ Non-Pun (both senses), enjoy a significant difference in relation to the other adopted strategies. Returning to the chi-square values of the two strategies taken up in the previous section and reviewing the preceding considerations in the section of data analysis, the fact reveals that in both strategies the lack of the pun in the target text is clear-cut. The former has been applied most often as a supplementary method in combination with the other strategies adopted for the purpose of compensation and mainly for recapturing special effects of the Persian couplets and finally for departing from a standard or literal language. As a matter of fact the high frequency of this strategy testifies the high creativity of Iranian translators in rendering poetry. As for the latter, it has made a significant difference among the other strategies by a majority of 165 instances. It is in the second status after the strategy of Pun $>$ RRD. It seems that this strategy is the most appropriate and easy-to-handle one for the purpose of conveying the meaning duality of a pun. In this study, wherever the two Iranian translators were unable to transmit the formal structures and even sound effects to the English version, the strategy of Pun $>$ Non-pun (both senses) was applied. Regarding the high frequencies and chi-square values of the strategies Pun $>$ RRD and Pun $>$ Non-Pun (both senses), it can be inferred that the two strategies are the most effective and neverfailing methods for rendering Sa'di's Ghazals.

Looking at the corresponding chi-square values of the four strategies Zero $>$ Pun, ST Pun=TT Pun, Pun $>$ Zero and Pun $>$ Pun, it can be deduced that their low frequencies imply that the four strategies have had lower applicability than the other four strategies. The strategy of Zero $>$ Pun has been frequently used for the purpose of compensation. This strategy can be supported by the translators' creativity. The other reasoning about low frequency of Zero $>$ Pun in this study can be the special text-type of Sa'di's Ghazals. It is needless to say that Sa'di's Ghazals enjoy the unique status among the canonized literature. Therefore, the modification of it even in the target text should be carried out with precaution. The same is true in Pun $>$ Zero case. The two least frequently used strategies of ST Pun = TT Pun and Pun $>$ Pun have made the significant differences in relation to the others. With regard to their corresponding chi-square values, it can be inferred that these strategies have been of very limited application.

It is clear that in Delabastita's (1996) description of the translation strategy of ST Pun=TT Pun, a literal translation method has been highlighted. As a matter of fact, in a literal translation method, the main characteristic of a pun; i.e. play on word, is effaced and lost. Therefore, since pun as a rhetorical device is contributed to beautify the poetry, the literal translation of it cannot transfer its aesthetic facet to the target text deservedly. It can be regarded as a convincing object for a limited application of this strategy by the Iranian translators. In the special case, even if one agrees with formal equivalence as the criteria of translatability, a few instances of recreating a pun like the original one in the English versions of Sa'di's Ghazals are the convincing proofs for rejecting the untranslatability of pun. The last strategy of the foursome group which were classified as the strategies with the statistical significant differences, is Pun $>$ Pun.

The final goal of the present study was to investigate the feasibility and the applicability of Delabastita's (1996) model to English translation(s) of the pun categories created in Sa'di's Ghazals. On the one hand, based on the analysis of English counterparts of Sa'di's Ghazals containing pun, the feasibility of the theoretical framework proposed by Delabastita (1996, p. 605) concerned with translating pun seems to be justified and on the other hand, through the findings and conclusions of this study, it can be deduced that nearly all strategies proposed in his model are applicable to English translation of the five pun categories. Eight strategies out of nine proposed in his theoretical framework have been more or less applicable by the two Iranian translators. Only one strategy, Editorial Techniques, was not ever employed in the two English versions.

As an ultimate result, Delabastita's (1996) set of techniques, in comparison with the other scholars' techniques proposed for translating pun or wordplay such as Offord (Shakespeare's puns, 1990), Weissbrod (Wordplay in general, 1996), de Veries \& Verheij (Bible wordplay, 1997), Wisselinck (Feminist puns in Daly, 1978) and Gottlieb (wordplay in subtitling, 1997), seems to fulfill the intended criteria of this study for the translation of the different pun categories. Although the points of similarity between such scholars' proposed strategies and Delabastita's (1996) set of techniques are partially considerable, what matters is that Delabastita's proposed strategies cover as many cases as possible and overlap only very little, if at all.

5.3 Implication of the study

This is a study about translation as much as it is about literature, there are several contributions and findings that it is hoped will be of interest and use to translators and translator trainers in the scope of the literary translation, in general, and pun translation, in particular. One of the contributions of the study is that it has not only provided an exact look at 
pun and its sub-types, in a classic sacred literary environment, but that the perspective has been broadened to examine applicable translation strategies for wordplay in general. Therefore, it is expected that the findings and conclusions of the present study would be specially useful guidelines for literary translators treating poems; for the reason that, in translation process of poems, they should consider not to neglect pun as a phonaesthetic element of poetry, on the effect that the linguistic nature of such concept demands to be untranslatable in its entirety.

Furthermore, the subtle hints of this study, on the one hand, will warn translators that the use of the strategies such as editorial techniques; including footnotes, endnotes, translator's comments in the foreword or afterword, explanations in parentheses, etc., should be ever adopted with discretion and even in some cases like this study, it has to be avoided. On the other hand, the present study will prepare the positions to refresh translators' memories of the language potentialities manifested in rhetorical devices such as rhyme, allusion, alliteration, referential vagueness, repetition and so on; as they shall treat freely in the process of pun translation and in a word, they shall get rid of the obsession from formal equivalence as a controversial issue in the translatability of concepts.

\section{Acknowledgements}

I would like to express my sincere gratitude to Dr. Bagheri and Dr. Shabani for their insightful suggestions, meticulous revisions of the text, assistance and patience during the course of the study.

\section{References}

A. English

Crisafulli, E. (1996). Dante's puns in English and the question of compensation. The translator: Studies in intercultural communication 2:2 (special issue: Wordplay and translation). PP. 259-276.

Delabastita, Dirk. (1993). There's a double tongue: An investigation into the translation of Shakespeare's wordplay, with special reference to Hamlet. Amsterdam \& Atlanta: Rodopi. PP.137-190.

Delabastita, D. (1994). Focus on the pun: wordplay as a special problem in translation studies. Target: International Journal on Translation Studies 6:2. 223-243.

Delabastita, D. (1996). Introduction. The translator: Studies in intercultural communication 2 (2) special issue: Wordplay and translation. PP. 127-139.

Delabastita, D. (ed.). (1996). Wordplay and translation. Manchester: St. Jerome Publishing.

Delabastita, D. (ed.). (1997). Traductio: Essays on punning and translation. Manchester: St. Jerome Publishing.

de Vries, A., \& Verheij, J.C. (1997). Wordplay in four twentieth-century translations of the Hebrew Bible. In: Delabastita, D. (ed.). Traductio: Essays on punning and translation. St. Jerome Publishing: Manchester. PP. 67-94.

Gottlieb, H. (1997). You got the picture? On the polysemiotics of subtitlingwordplay. In: Delabastita, D. (ed.). Traductio: Essays on punning andtranslation. New York: St Jerome. 207.232.

Landheer, R. (1989). L'ambigute: Un De'o fi Traductologique. Meta. (1): 24.

Nash, W. (1985). The language of humour: Style and technique in comic discourse. London: Longman.

Newmark, P. (1988). A textbook of translation. Oxford: Pergamon Press.

Offord, M. (1990). Translating Shakespeare's word Play. In: Fawcett, P., \& Heathcote, O. (eds.). Translation in performance: Papers on the theory and practice of translation. Bradford Occasional Papers 10. Bradford: University of Bradford, Department of Modern Languages. 101.140. In: Delabastita, D. (1994). Focus on the Pun: Wordplay as a Special Problem in Translation Studies. Target, $6:(2), 223-243$.

Offord, M. (1997). Mapping Shakespeare's puns in French translations. In: Delabastita, D. (ed.). Traductio: Essays on punning and translation. New York: St Jerome. 233.260.

Schröter, T. (2005). Shun the pun, rescue the rhyme?-The dubbing and subtitling of language-play in film. Karlstad: University of Karlstad.

Toury, G. (1997). What Is It That Renders a Spoonerism (UN) translatable? In: Delabastita, D. (ed.). Traductio: Essays on Punning and Translation. New York: St Jerome. 271. 291.

von Flotow, L. (1997). Mutual pun-ishment? Translating radical feminist wordplay: Mary Daly's 'Gyn / Ecology' in German. In: Delabastita, D. (ed.). Traductio, Essays on punning and translation. Manchester: St. Jerome Publishing. 45-66.

Weissbrod, R. (1996). Curioser and curioser: Hebrew translations of wordplay in Alice's Adventures in Wonderland. In Delabasitita, D. (ed.). The Translator: Studies in intercultural communication 2:2, special issue: Wordplay and Translation. 219-234.

B. Persian

$$
\begin{aligned}
& \text { تجليل، جليل. (1988/1367). }
\end{aligned}
$$

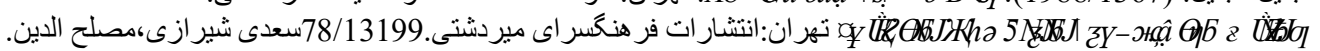

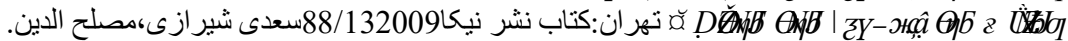

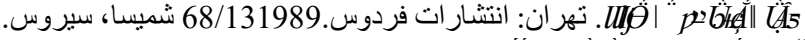

$$
\begin{aligned}
& \text { 1367/1988 همايى، جلال الدين. }
\end{aligned}
$$

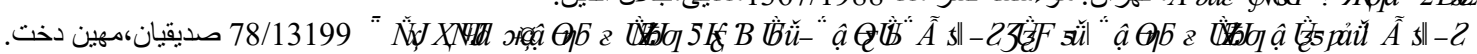

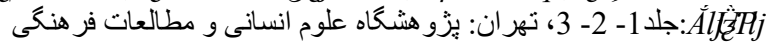

